\title{
WAYS OF DESCRIBING NENETS AND KHANTY "CHARACTER" IN 19th CENTURY RUSSIAN ETHNOGRAPHIC LITERATURE
}

\section{Art Leete}

The current article deals with general assertions about the natives of West-Siberia as bearers of their world view conception in the Russian ethnographic literature of the last century. The aim of the article is to explain the general or background attitudes towards the Khanty and Nenets people in the 19th century (as well as towards their world view) in ethnographic literature during the period under discussion.

A certain attitude towards the natives of the northern part of WestSiberia - the Khantys and the Nenets - was established by the 19 th century authors and, at a certain level this attitude can be observed even in contemporary ethnographic texts. Golovnev for example argues that for a long time the principal researcher of the Samoyed people was Castrén, the most important contributor to the study of Ob-Ugric people was Munkácsi. Their renditions and assessments formed the basis of comparison for all the future generations of scientists. This quality to remaining a so-called "paragon of truth" was determined by the methodological unprejudiced ideas in the first flux of research.

The arguments of the authors were mainly of personal kind. It is no coincidence that a number of research papers were written in form of journals. None of the authors had made an attempt to comprise culture as a whole, all of them merely tried to observe and disclose as much of the matter as possible. The scientific works of these years constitute the epoch of discovery of the Samoyed-Ugric cultures or the interpretation of these cultures into European languages (Golovnev 1995: 12).

It is not quite certain, however, how this estimation applies to Castrén - he is rarely mentioned directly. Still, upon the completion of this article the study on this subject was in its initial stage 
and I can merely present tentative hypotheses on the description of the Ob-Ugrians and the Nenets in the ethnographic literature of the last century. The lack of references to Castrén and Munkácsi is partly caused by the fact that, at that post-Castrénian period, the methodology of ethnography did not oblige the naming of all the sources. At the same time it is more difficult for today's researchers to determine all the possible connections.

The image of Khantys and Nenets in the publications of the authors discussed below, is a certain outlook on these cultures and on the 'character' of the bearers of these cultures. The disposition has not taken place in a unique and decided manner. Although Castrén seems to be the 'pathfinder' in many ways, the general image of the Ob-Ugrians and the Nenets has formed gradually by the accumulation of somewhat similar attitudes or estimations passed on from author to author.

Also, we should not consider the representation of the identity of the Ob-Ugrians and Samoyeds in the 19th century ethnology to be what Golovnev calls the original "first flux". Castrén might be regarded as a role model or a paragon by the later scientists, but in fact he functions as a digest of the period of research previous to his time. The reason for this is that Castrén elaborates several 18 th century (and even earlier) stereotypes of representing the Nordic people in perfection. At the same time some of Castrén's innovations (which might not be considered as totally original, though) are significant even for the principles of studying the identity of the Nordic people.

We will not enter into the closer analysis of Castrén's ideas here and instead focus on the other authors as they appear in certain discussions, without giving an overview of their theoretical background or specific role models. Our aim here is to show that the authors of the 19th century, even without Castrén make up quite a substantial tradition of study. At least they do not appear to have suffered from a lack of ideas. 


\section{WAYS OF DESCRIBING THE BASIC CHARACTERISTICS OF OB-UGRIC AND NENETS PEOPLE IN THE WORKS OF 19th CENTURY RUSSIAN AUTHORS}

Some of the presented descriptions of the characteristic features of the natives of West-Siberia could be the following.

According to Beliavski the Khantys have been characterised in the following way:

They are modest, quiet ${ }^{1}$, laconic and composed. Being kindhearted neighbours they are fond of domestic life, they are honest, faithful and benevolent (Beliavski 1833: 70).

Beliavski compares the Khantys and the Nenets in the following way:

The Samoyed people $e^{2}$ are even more kind-hearted than the Ostyaks, ${ }^{3}$ wise, smart, reliable and somewhat stubborn (Beliavski 1833: 159).

One of the features of the Samoyed people which is different from that of the Ostyaks is that while not being vindictive they are short-tempered without any serious consequences (ibid. : 160).

V. Islavin describes the general situation of the Nenets people in the tundra of the Archangelsk province before the Russian and Komi invasion in as follows:

Accustomed to the gloomy sky and dreary nature the Samoyed people wandered in the tundra peacefully and free from cares (Islavin 1847: 11).

Islavin also calls these times as "blessed" for the Nenets people (Islavin 1847: 96).

Islavin takes this conception of the Nenets even further, regarding them as natural people, formed by the surrounding landscape and climate:

/--- / A Samoyed having grown up in a harsh climate has grown together with severe cold and blizzards in a manner that he endures the severest frost better than room temperature. It hap- 
pened to me that sometimes lodging in a cold cottage I couldn't be without a fur coat made of reindeer skin. At the same time I could see how my Samoyed pathfinders left the cottages one by one and stayed outside and spent the night curled up on a sledge $e^{4}$ or just fallen in the snow (Islavin 1847: 28).

Here we can see a certain conformity with the ideas of Rousseau (though based solely on personal experience) an image of native people who live happily and naturally before the interference of civilisation. So much the more because after the contacts with the Russians and Izhma-Komis, Islavin characterises the Nenets people as addicted to liquor, helpless and incalculable, therefore - "eternally doomed" (Islavin 1847: 21-22).

Similarly to some earlier and more recent authors Islavin describes the Nenets as hopelessly unkempt and dirty (Islavin 1847: 27, 29).

Islavin also presents a concept of the Nenets which could be met also in some more recent treatments. Namely, he describes the Nenets as people who are careless, living in any given moment:

The Samoyeds / --- / supply generally only little amounts of food. Many of them do it because storing food causes difficulties in their nomadic life. But mostly it is the result of their innate carelessness. A Samoyed eats while he has something to eat and does not contemplate on future. But if the period of starving sets in he sits by the fire and drowsily spits into it, contemplating how to get out of trouble (Islavin 1847: 36-37).

Islavin also argues that the Nenets are a brave people since they do not assess their life, which offers neither happiness nor sorrow (Islavin 1847: 66). Here, the treatment of Islavin coincides again with the concept of some more recent authors, as, according to Islavin the desperate life of the Nenets is the result of their working as herdsmen in the reindeer herds of the Russian and IzhmaKomis (Islavin 1847: 66). Therefore, Islavin says, a Nenets posesses a certain proletarian mentality.

Describing the character of the Nenets, Islavin makes a distinction between the Nenets of the Timan and Kanin tundra and the Nenets of the Bolshezemelsky (or Big Land) tundra. The latter dif- 
fer from the Nenets of the Timan and Kanin tundra by their closer association with the Russians which has made them more deceitful:

/---/ socialising more with the Russians who are responsible for their impoverishment the Nenets themselves have become so smart that they often cheat even their masters, the Russians themselves (Islavin 1847: 80).

N. Abramov who discovered the manuscript The Short Characterisation of the Khanty People compiled in 1715 by Novitski (Novitski 1973) has in his article on the Christianization of the Khanty people employed the same manuscript (which, in fact, had not been published by the time the Abramov's article came out) and the 18th century History of Siberia by Müller (Müller 1941). Although describing the Christianization of the Khantys, Abramov uses, beside Müller's History and Novitski's Characterisation, other archival documents, so his treatment is far from identical with that of Novitski's and Müller's, therefore it has to be treated separately. Abramov focuses in his 1851 article mainly on desribing the spread of Christianity, so his text does not include too many original statements about the nature of the Khantys. Still, we should mention the ones that could be found there.

Namely, Abramov calls the minds of the Khantys "roughly materialistic" (Abramov 1851: 2). He also refers to the Khantys as "a rough people", "rough heathens" (Abramov 1851: 10, 11), "simple gentle natives" (ibid. : 18). But as all these characteristic features are presented in the context of Christianisation, such as - "arrogant idolaters" (Abramov 1851: 13), it would be more sensible to discuss the matter separately in the context of the connection between the religion of the natives of West-Siberia and Christianity. But as it would bring along a number of additional problems which should be discussed as well, we will limit the introduction of Abramov's treatment to a brief outline by I. S. Poliakov, on the other hand, describes the general characteristics of the Khantys as following:

An Ostyak cannot restrain himself from any passion, be it physical or ethical (Poliakov 1877: 56). 
O. Finsch and A. Brehm note the following about the Khanty and Nenets people:

The Samoyeds seem to be generally more lively and more agile than the Ostyaks. Timidity, fear and bashfulness perceived at the first meeting will disappear after a prolonged period of living together. These qualities are not a sign of their cowardice (Finsch \& Brehm 1882: 456).

Different authors disagree in their somewhat resolute decisions. Similarly to Finsch and Brehm Beliavski attributes the Nenets a more agile and abrupt temper. Bartenev, however, has a totally different opinion of the comparison between the Nenets and Khanty people; his view will be discussed further below.

Finsch and Brehm describe the impact of civilisation on the character of the people in the northern part of West-Siberia in the following way:

European persecution has changed the character of the natives instilling reticence, thoughtfulness, languidness and insensibility /--- / on a closer acquaintance with the natives you will notice that they are, on the contrary, very cheerful (Finsch \& Brehm 1882: 456).

According to A. Jacobi, professor of the University of Kazan, the Khantys of Kazym are

/--- / honest in their duties and following the ancient traditions expect such an honesty from others - even from the Russian merchants whom they trade with (Jacobi 1895: 10-11).

Jacobi discusses the general characteristics of Nordic people as following:

A strong belief in the insecure future is the best gift of the North, the actions and thoughts of the local are based on it and it gives these people this special noble tranquillity and a hint of carelessness which made the former warship sailors so amiable. This shade of character can also be observed by the free miners in the deep shafts of Saxony whose traditional greeting is: "Glück auf!". Old, grey-haired war veterans are the same. And the very same 
feature could be found in the nature of the natives of Far-North. And the closer to the north-pole, the clearer it is. To put it briefly everywhere where putting one's life at risk is a rule (Jacobi 1895: $22)$.

As far as the formulation of "poletarian existentialism" of the Arctic peoples is concerned, Jacobi is "insuperable". Nevertheless several other are able to draw such far-reaching comparisons. Castrén, for example, compares the Khantys with Norwegian fishermen (Castrén 1860: 196). The first employer of such a method of comparison, however, was the Dutch navigator van Linschoten who described the Nenets people similarly to the Spanish and Dutch peasants in the 1594 and 1595 journals of his voyage to the Arctic (van Linschoten 1915).

One of the most intriguing studies about the Khantys at the end of the last century was written by V. Bartenev:

You always feel at home among these savages. The Ostyaks are a very kind and honest people (Bartenev 1896: 75).

Also:

The Ostyaks, if you associate with them personally, are very pleasant - they leave the impression of a quiet, good-hearted and honest people (Bartenev 1896: 99).

Bartenev describes the relationship between the individual characteristics and the environment of the Khantys and Nenets as following:

Due to the lack of agricultural and manufacturing industry the natives of Obdorsk are deprived of a secure basis for mental progress. Things are even worse for the nomadic Samoyeds - the nomadic reindeer breeders may live tens of thousands of years without any change.

As to the Ostyaks, their fishing is also unfavourable for progressive advancement. So much the more because it takes place in the harshest conditions /--- /

But even if the Ostyaks could be freed from their load of debt and share in the well-organised state program of the sale of primary necessities (as in Greenland under Denmark), to civilise 
this people would take a lot more. The Ostyaks, namely, share a trait characteristic to all the savages - Spencer calls it impulsiveness. An Ostyak lives in a certain moment of time and is not in the least provident (Bartenev 1896: 80-81).

V. Bartenev also considers the influence of civilisation as a significant factor in the development of the psychological features of the natives of West-Siberia. At that he regards the contacts with civilisation as destructive for the natives:

It seems to me that every savage nation whose growth is limited by climate is irrevocably doomed after contact with civilisation (Bartenev 1896: 57).

Bartenev's version of the differences of the Khantys and the Nenets is also ingenious:

The Samoyed-Mongols ${ }^{5}$ are different from the Ostyak-Finns ${ }^{6}$ in their personality: the Samoyeds are not as expansive or talkative, they keep a mien of rough dignity. The Ostyaks, on the other hand are an expansive, cheerful, loquacious and inconceivably witty people (Bartenev 1896: 71).

At this point we should recall that Beliavski, as well as Finsch and Brehm drew a comparison exactly opposite to Bartenev's - that it were the Ostyaks who were calm and peaceful and the Samoyeds who were aggressive.

According to Bartenev the natives of the northern part of WestSiberia scarcely ever suffer from mental disorders:

Cases of mental disturbances occur very seldom indeed. Similarly, the natives suffer rarely from the omeriachenie [Arctic hysteria] - a disease which occurs frequently among the Yakuts in East-Siberia. Occasionally the Ostyaks suffer from hallucinations: they see devils. A devil appears in a desolate place in a human shape, he is dressed like a human but has red eyes. He appears very suddenly, bursts into laughing and disappears (Bartenev 1896: 65).

A few pages down Bartenev adds: 
Anyway, if a Samoyed leads a secure life, i. e. owns enough reindeer and a decent set of furs, he is always healthy as a horse and shows no signs of degeneration or extinction (Bartenev 1896: 70).

S. Patkanov, without discussing the nature of the Khantys and Mansis any further, points out that after subjection to the Russian empire (obviously he means the 16th-17th century) they were still "the children of nature" (Patkanov 1898: 351).

In a description of his journey that took place during 1856-57 (published only at the beginning of the 20th century), S. V. Maksimov writes the following about the European Nenets (the description is presented as a conversation between Maksimov and his Russian pathfinder):

They seem to be a peaceful nation.

Peaceful, kind! /--- / peaceful, only if they tipple they become impetuous, accosting people, looking for trouble. And if you shout or show your fist at them they don't even flinch and accost you even more. But when sober they are peaceful as reindeer (Maksimov 1909b: 380).

Maksimov describes further the relationship of the Nenets and drinking:

/--- / they are natural born tipplers. At their community even the small children drink vodka instead of milk, the women drink, everybody drinks /---/ (Maksimov 1909b: 379).

One of the interlocutors told Maksimov the following about the drinking habits of the Nenets:

You can drink as much vodka with a Samoyed as you like, but you have to hurry and get drunk faster and leave the yurt, otherwise a drunken Samoyed might pick a fight with you (Maksimov 1909c: 109).

Maksimov also writes:

The Samoyeds as every other backward people are merely prisoners of ancient times (Maksimov 1909c: 104). 
Maksimov claims (although again via his interlocutor) that the Nenets are "a totally ignorant people", basing his argument on the fact that the Nenets are not aware of their age and do not live in houses like Russians do (Maksimov 1909b: 382). He also calls them naïve (Maksimov 1909c: 117). He characterises a Nenets shaman with epithets like "half-savage", "halfway religious maniac" and "half-impostor" (Maksimov 1909c: 105).

Describing a seal hunt on the coast of the Kanin peninsula, Maksimov writes quite rudely about the Nenets:

But such patience - waiting on the waterline for an animal for days - could only be attributed to the half-idiots of the Samoyed tribe (Maksimov 1909a: 40).

He also calls them dirty and characterises their existence as "a dog's life" (Maksimov 1909b: 16). Maksimov refers to their filthiness again (Maksimov 1909c: 101), and calls the Nenets "half-savage", "patriarchal and short-sighted" and "careless" (Maksimov 1909c: 117, 118). He also considers them as insensitive, illustrating it with a situation where he inquires a Nenets woman about her life:

The Samoyed woman gives all the answers with such a calm intonation as if answering questions: does she eat, sleep or ask for a crumb (Maksimov 1909c: 118).

Describing his meeting with the Nenets in their yurt Maksimov notes that the "Samoyeds" received him in "perplexity and confusion" (Maksimov 1909c: 94, 96).

At the same time Maksimov describes them performing domestic works (sewing their coats, carving toys, scraping hides) and notes:

It was all performed in a deep focused silence (Maksimov 1909c: 95).

Maksimov contemplates on the reasons of "simplicity" of the Nenets culture, viewing the Nenets as dependants of reindeer:

This is why the Samoyed always depend on the whims of reindeer: the latter need fresh food and new places constantly and 
that is why they set up their yurts where the instinct of the animals takes them. That is why the whole life of the Samoyeds is closely connected to the phenomena of the animal existence of reindeer. The animals will inevitably look for food where it could be found - so the Samoyeds follow them as loyal servants. This also justifies the nomadic life of this North-Russian native tribe and all the simpler customs and external ritual phenomena of domestic life (Maksimov 1909c: 97).

Maksimov also shares his comments on the difference of character of the Komis and Nenets:

Smart and pragmatic Komis who had several possibilities to observe the character of their insensitive neighbours have come to a completely positive and accurate conclusion that the Samoyeds, destined to fight nature and the numerous obstacles thrown at their way by nature for centuries, are truly hard-working. They can tell by the fact that some of them never work and just sit around. The Komis also know that the hard-working and patient Samoyeds are whole-heartedly loyal to a promise: if a person who made a promise happened to die, his place was taken over by his brother or some other relative (these are recent facts). If a Samoyed wishes to cheat on someone he will be caught on the act very easily (Maksimov 1909c: 109).

Maksimov also describes how the Nenets have learned to lie from the Izhma-Komis:

The shady business of the neighbours has waken the self-consciousness and even revenge of the Samoyeds as could be proven by recent examples. A Samoyed once sold a resident of Pustozersk the furs of arctic fox for a certain amount of bread and drank for the agreement. The resident of Pustozersk got drunk faster and fell asleep. The Samoyed lost neither his awareness nor self-control and left with the money and the sold furs. The next day he sold the furs to another farmer and the third day "disappeared into the tundra where no-one can track him down even with hounds," as one of the victims put it (Maksimov 1909c: 114). 


\section{CONCLUSIONS}

The presented arguments about the Khanty and Nenets people which seem quite contradictory at first might be reduced to a general conception of 4 factors which had influenced the development of the natives of West-Siberia.

1. The Finno-Ugric, Uralic origin - only Bartenev mentioned that (1896).

2. The common spirit of Siberia, which is caused by the influence of nature and environment. It is emphasised mostly by Islavin (1847), but to some extent also by Maksimov (1909c).

3. The influence of civilisation, which is observed by a number of authors (Islavin 1847; Finsch \& Brehm 1882; Bartenev 1896; Maksimov 1909).

4. A seemingly intuitive central idea (which also refers to the landscape and lifestyle) that certain conditions are in a way similar to other conditions for the existence of "universal proletariat", "universal social marginal groups". This factor could also be called "Proletarian existentialism". Jacobi (1895) expresses it probably in the best way by pointing out far-reaching parallels between the Khanty people and the Saxon miners or between other marginal cultural groups. The social marginality of the Nenets is also discussed by Islavin (1847) and as mentioned before, by Castrén (1860).

Such presentation of only four factors is highly deterministic. The Khantys and Nenets are presented as a product of a given environment and conditions. It is as if they did not have an active say in their nature. As if they did not shape their features or personalities themselves. They merely represent the cumulative effect of external conditions. Perhaps we may thus establish the primary hypothesis of the ethnographic descriptions of the Nenets and Khantys of the 19 th century. In those days no attention was paid to the cultural categories of identity.

The 19th century Russian authors treated in this paper are littleknown today. The "avant-garde" of the 19th century research on the Khantys and Nenets is not represented by them but rather by 


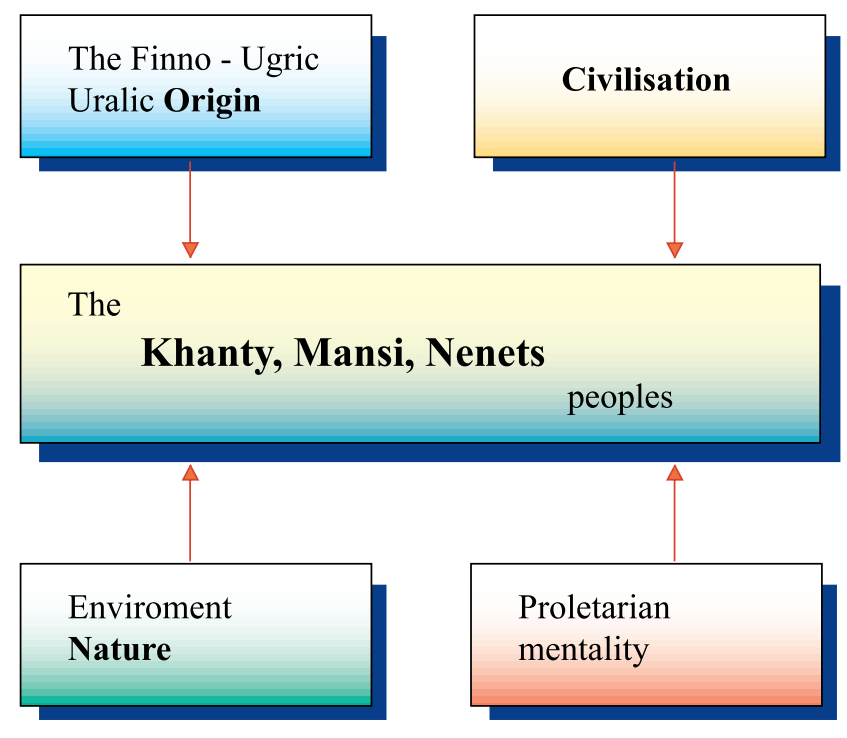

Castrén and Munkácsi. Such descriptions have been presented by a number of authors, forming the "average science" of the 19th century. The current paper was a first brief treatment of an extremely limited set of problems and selection of sources of the descriptions of the Nenets and Khanty character in the 19th century Russian ethnographic literature. At the same time, this short discussion shows that the kind of deterministic views on the character of the Khantys and Nenets were typical of the 19th century Russian ethnography.

Translated by Kait Realo

\section{Comments}

${ }^{1}$ It seems appropriate to present at least one text sample of Castrén since it also characterises his method of description which is far more eloquent, thorough and attentive than that of most of the authors discussed in the current article.

Castrén's viewpoint to the Nenets (hereby he refers to the type of a typical native) "character" is at places remarkably adequate, as it includes also a certain hint to the question of how the 19th century 
researchers' and travellers' knowledge about the general characteristics of such tundra and taiga people is obtained:

Members of our colourful circle enjoy themselves quite differently from each other. A Russian sings cheerful songs, makes jokes and laughs, acts like a fool. A Komi says prayers, tells the life stories of saints and holds moralising talks. A Samoyed sits by himself and listens attentively to the wiser talkers (Castrén 1860:175).

Therefore, Castrén has described one of the main characteristic features of the Ob-Ugrians and Nenets of the 19th century - their quiet nature - situationally, as opposed to the categorical-declarative phraseology of the other authors.

${ }^{2}$ In the scientific literature of the 19 th and the beginning of the 20th century all Samoyed peoples went under the same common name. Of all the Samoyed people only the Nenets are treated in the current paper. The ancient name form has been preserved in the quotations.

${ }^{3}$ Until the beginning of the 20th century the Khanty people were called Ostyaks and the Mansi people Voguls. Such name forms have been preserves also in the quotations. Next to the Khantys the Sölkup people were also called Ostyaks (or Ostyaks-Samoyeds).

${ }^{4}$ Most probably, V. Islavin refers to the narta.

5 The Samoyed-Mongol people - it is not quite clear what Bartenev refers to. He might mistakenly consider the Nenets as belonging to the Altai language group or the Mongoloid race.

6 The Ostyak-Finnic people - refers most probably to the fact that the Khanty language belongs to the Finno-Ugric branch of the Uralic language group.

\section{References}

Abramov, N. 1851. O vvedenii khristianstva u Berezovskikh Ostiakov.Zhurnal Ministerstva Narodnogo Prosveshchenia,LXXII, o. V. Sankt-Peterburg, pp. 1-22. 
Bartenev, V. 1896. Na Krainem Severo-Zapade Sibiri. Ocherki Obdorskogo kraia. Sankt-Peterburg.

Beliavski 1833. Poezdka k Ledovitomu Okeanu. Moskva.

Castrén 1860. PuteshestvieAleksandra Kastrena po Laplandii, severnoi Rossii i Sibiri (1838-1844, 1845-1849). Magazin Zemledelia i Puteshestvii. Geograficheskii Sbornik Nikolaia Frolova. Tom. VI. Sobranie Starykh i Novykh Puteshestvii. II. Moskva.

Finsch, O. \& Brehm, A. 1882. Puteshestvie v Zapadnuiu Sibir'. Moskva.

Golovnev, A. B. 1995. Govoriashchie kul'tury. Traditsii samodiitsev $i$ ugrov. Yekaterinburg.

Islavin, V. 1847. Samoedy v domashnem i obshchestvennom bytu. Sankt-Peterburg.

Jacobi, A. I. 1895. Ostiaki severnoi chasti Tobol'skoi Gubernii. Ezhegodnik Tobol'skogo Gubernskogo Muzeia. Vyp. IV, pp. 1-25.

van Linschoten, G. 1915. Niderlandskaia ekspeditsia k severnym beregam Rossii v 1594-1595 gg. Zapiski po Gidrografii. Petrograd. Tom XXXIX, vyp. 3., s. 480-506; vyp. 4., pp. 570-584.

Maksimov 1909a = Sobranie sochinenii S. V. Maksimova. Tom vos'moi. God na Severe. I. Sankt-Peterburg.

Maksimov 1909b = Sobranie sochinenii S. V. Maksimova. Tom deviatyi. God na Severe. II. Sankt-Peterburg.

Maksimov $1909 \mathrm{c}=$ Sobranie sochinenii S. V. Maksimova . Tom desiatyi. God na Severe. III. Sankt-Peterburg.

Müller, G. F. 1941. Istoria Sibiri. II. Moskva, Leningrad.

Novickij, G. 1973. Kratkoje opisanie o narode ostjackom. Rövid leiras az osztjak nepröl (1715). Studia Uralo-Altaica III. Szeged 1973.

Patkanov, S. 1898. Skazania o poezdkakh ostiatskikh kniazei k russkim tsariam.Zhivaia Starina. Periodicheskoe Izdanie Otdlenia Etnografii Imperatorskogo Russkogo Geograficheskogo Obshchestva. Vyp. III, IV. Sankt-Peterburg, pp. 351-356.

Poliakov, I. S. 1877. Pis'ma i otchety o puteshestvii v dolinu r. Obi. Prilozhenie k XXXmu tomu Zapisok Imp. Akademii Nauk. Vyp. 2. Sankt-Peterburg. 